\title{
Synthesis of novel pyrazoline-thiazolidin-4-one hybrids and evaluation of their biological activity
}

\author{
Serhii M. Holota ${ }^{1,2} *$ \\ ${ }^{1}$ Danylo Halytsky Lviv National Medical University, 69 Pekarska St., Lviv, 79010, Ukraine \\ ${ }^{2}$ Lesya Ukrainka Volyn National University, 13 Voli Ave., Lutsk, 43025, Ukraine
}

\begin{abstract}
In the present work, the synthesis of pyrazoline-thiazolidin-4-one hybrids and their pharmacological properties are described. The structure of compounds is characterized using ${ }^{1} \mathrm{H},{ }^{13} \mathrm{C}$ NMR, and LC-MS spectra. The antioxidant (DPPH assay), antimicrobial (Gram-positive bacterium Lactobacillus plantarum, Gram-negative bacterium Escherichia coli, and yeasts Candida albicans, MIC determination), redox (cyclic voltammetry) as well as herbicidal activity (against grass species Agrostis stolonifera) of compounds have been studied. All derivatives have demonstrated radical scavenging activity with $\mathrm{IC}_{50}$ values in the range of 4.67-7.12 mM that were measured by the DPPH test. The tested compounds showed very low antimicrobial and herbicidal activity and no redox peaks were observed in the cyclic voltammetry studies.
\end{abstract}

Keywords: pyrazoline-thiazolidin-4-ones hybrids; DPPH assay; antimicrobial/herbicidal activity; cyclic voltammetry.

\section{Introduction}

The last decade has witnessed a growing interest in the development of redox modulating agents as effective tool in therapy oxidative-stress associated processes: cancers, diabetes, inflammatory diseases, neurological disorders, and others [1-4]. In this context, the structure modified thiazolidin-4-one and pyrazoline nucleus are prospective molecular platforms for design antioxidants and redoxmodulating agent design [5-8]. For example, the application of the mentioned scaffolds is an attractive direction for the development of selective modulators of Nrf2 and NF-kB transcription factors, that play a key role in the regulation of cellular responses to oxidative-stress factors and are potential drug targets [9-11].

In our early-described researches some types thiazolidin4-one hybrids linked through "enamine" linker at C-5 has

\begin{tabular}{ll}
\hline Received: & 10.02 .2021 \\
Revised: & 25.03 .2021 \\
Accepted: & 12.04 .2021 \\
Published online: & 30.06 .2021 \\
\hline
\end{tabular}

* Corresponding author. Tel.: +380-97-226-0066;

e-mail: golota_serg@yahoo.com (S. M. Holota)

ORCID: 0000-0002-9892-437X been synthesized and several compounds been have been identified with a high level of antibacterial and antifungal [12-14], anticancer and trypanocidal [15], and antiinflammatory activity [16] (Figure 1). In our opinion, the 5-aminomethylidene derivatives have several important advantages in synthetic variability and structure optimization processes compared to 5-ylidene analogous.

On the other hand, the pyrazolines possess a wide range of biological activities and belong to unsaturated heterocycles that can be oxidized to the corresponding pyrazoles [17]. These properties are of great interest in the design and development of potential redox-active compounds as possible pharmacological agents.

Taking into account the above reasons, the main goal of the present work was the design and synthesis of novel "enamine"-bearing pyrazoline-thiazolidin-4-one hybrid molecules and further evaluation of their antioxidant, antimicrobial, herbicidal, and redox activities.

\section{Results and Discussion}

The synthetic design included two key routes (Scheme 1). Initially, the derivatives $\mathbf{2 a}, \mathbf{b}$ were easily obtained using Holmberg's protocol (i) [18] from corres-

(C) Holota S. M. et al. This is an open-access article distributed under the terms of the Creative Commons Attribution License, which permits unrestricted use, distribution, and reproduction in any medium, provided the original author and source are credited. 
<smiles></smiles>

In vivo activity on carrageenan- and formaline-induced oedema models in dose $50 \mathrm{mg} / \mathrm{kg}$. No ulcerogenic, hepatotoxic action

\section{Antiinflammatory activity Holota S. et al. Biopolymers\&Cell, 2019}<smiles>[R]CCC1(NC[R])SC(=S)N(C(Cc2ccccc2)C(=O)OCC)C1=O</smiles>

$\mathrm{R}=4-\mathrm{COOEt}_{-} \mathrm{C}_{6} \mathrm{H}_{4}$

Trypanosoma brucei brucei $I_{50}=0.091 \mu \mathrm{M}, \mathrm{SI}=409.4$; Trypanosoma brucei gambiense $\mathrm{IC}_{50}=0.027 \mu \mathrm{M}, \mathrm{SI}=1396.2$

$\mathrm{R}=5-\left(2,4-\mathrm{Cl}_{2}-\mathrm{C}_{6} \mathrm{H}_{3}\right)$ thiazol-2-yl;

NCI DTP assay:

MG_MID $\mathrm{GI}_{50} / \mathrm{TGI}=2.57 / 57.27 \mu \mathrm{M}$<smiles>CCSS(=O)(=O)c1ccc(NCC2CCCC23SC(=O)NC3=S)cc1</smiles>

Wide spectrum of antibacterial and antifungal activity with MIC values in $\mu \mathrm{M}$ range

Antimicrobial activity Derkach G. et al. JOrgPhCh, 2016

\section{Trypanocidal and anticancer activity Holota S. et al. Bioorganic Chemistry, 2019}

Figure 1. The "enamine"-bearing thiazolidin-4-one hybrids as potential pharmacological agents.

ponding aminobenzoic acids 1a, b. The procedure (ii) [15] was used for synthesis $\mathbf{3 a}, \mathbf{b}$ from obtained derivatives 2a, b. The convenient synthetic approach [19] starting from aromatic aldehyde $\mathbf{4 a}, \mathbf{b}$, and acetophenone (iii and $i v$ ) was used for the synthesis of diarylpyrazolines $\mathbf{6 a}, \mathbf{b}$. The target pyrazoline-thiazolidin-4-one hybrids 7a-d were synthesized in satisfactory yields and purity by reacting compounds 3a, $\mathbf{b}$ and 6a, b under reflux in ethanol for 30-45 min.

The structures of all synthesized compounds were confirmed by ${ }^{1} \mathrm{H},{ }^{13} \mathrm{C}$ NMR spectroscopy, and LC-MSspectrometry. Esterification of the carboxylic group of compounds 3a, $\mathbf{b}$ under condition $i i$ was observed by the appearance of signals from the protons of the ethyl group at $\sim 4.31(\mathrm{q}, J=6.3 \mathrm{~Hz})$ and $\sim 1.31(\mathrm{t}, J=6.3 \mathrm{~Hz}) \mathrm{ppm}$ in the ${ }^{1} \mathrm{H}$ NMR spectra. In the ${ }^{1} \mathrm{H}$ NMR spectra of derivatives 3a, $\mathbf{b}$ and 7a-d the proton signal at C-5 double bond appears mainly in the field of aromatic protons, and only for derivative $\mathbf{7 b}$ it was observed as a singlet at $7.60 \mathrm{ppm}$. The pyrazoline fragment of compounds 7a-d shows the characteristic patterns of the AMX system for $\mathrm{CH}_{2}-\mathrm{CH}$ protons.

The synthesized compounds 7a-d have been evaluated for their antioxidant activity in vitro in the DPPH (1,1-diphenyl-2-picrylhydrazyl) radical scavenging assay [20] in the conditions close to physiological (serial dilutions of stock methanol solutions at six concentrations of 1.0, 2.0, 4.0, 6.0, 8.0, $10.0 \mathrm{mM}+$ Tris- $\mathrm{HCl}$ buffer $\mathrm{pH}=7.40$, measurements after $60 \mathrm{~min})$. Ascorbic acid was used as a reference compound (standard). The $\mathrm{IC}_{50}$ values have been determined for compounds 7a-d as well as ascorbic acid to characterize their antioxidant activity (Figure 2).
As a result, the tested compounds 7a-d have lowmoderate activity in DPPH assay, and the established $\mathrm{IC}_{50}$ values of the synthesized compounds were: $4.67 \mathrm{mM}(\mathbf{7 a})$, $5.90 \mathrm{mM}$ (7b), $6.05 \mathrm{mM}$ (7c), $7.12 \mathrm{mM}$ (7d), and for ascorbic acid $\mathrm{IC}_{50}=0.045 \mathrm{mM}$. It should be noted that this level of antioxidant activity may be more likely associated with the presence of phenolic $(-\mathrm{OH})$, and dimethylamino groups $\left(-\mathrm{N}\left(\mathrm{CH}_{3}\right)_{2}\right)$ in compounds 7a-d than with other molecular fragments. Nevertheless, all tested derivatives show activity from 8.38 to $13.43 \mathrm{mg} / \mathrm{mL}$ that is promising for searching for new potential antioxidants among this subtype of hybrid molecules.

Compounds 7a-d were preliminary screened for their potential antimicrobial activity against Gram-positive bacteria as Lactobacillus plantarum, Gram-negative bacteria as Escherichia coli, and yeasts (Candida albicans). Antimicrobial activity was evaluated in terms of minimum inhibitory concentrations (MICs), and the values were compared with standard reference antimicrobial agents [21-22]. Overall, the tested compounds showed very low antimicrobial activity against the $E$. coli and $C$. albicans compared to the reference drugs $(36.5 \mu \mathrm{M}$ for ampicillin and $38.96 \mu \mathrm{M}$ for fluconazole), Table 1. Only derivative 7c showed activity with MIC value of $1.25 \mathrm{mM}$ against $E$. coli, and derivative $\mathbf{7 d}$ showed antifungal activity against C. albicans with MIC value of $1.25 \mathrm{mM}$. It is also worth noting that compounds $\mathbf{7 a - d}$ were inactive against L. plantarum.

The herbicidal activity of the compounds 7a-d was tested against the monocot grass species Creeping bentgrass (Agrostis stolonifera). Methanol solutions at the concentration of $1 \mathrm{mg} / \mathrm{ml}$ of all compounds were added to 


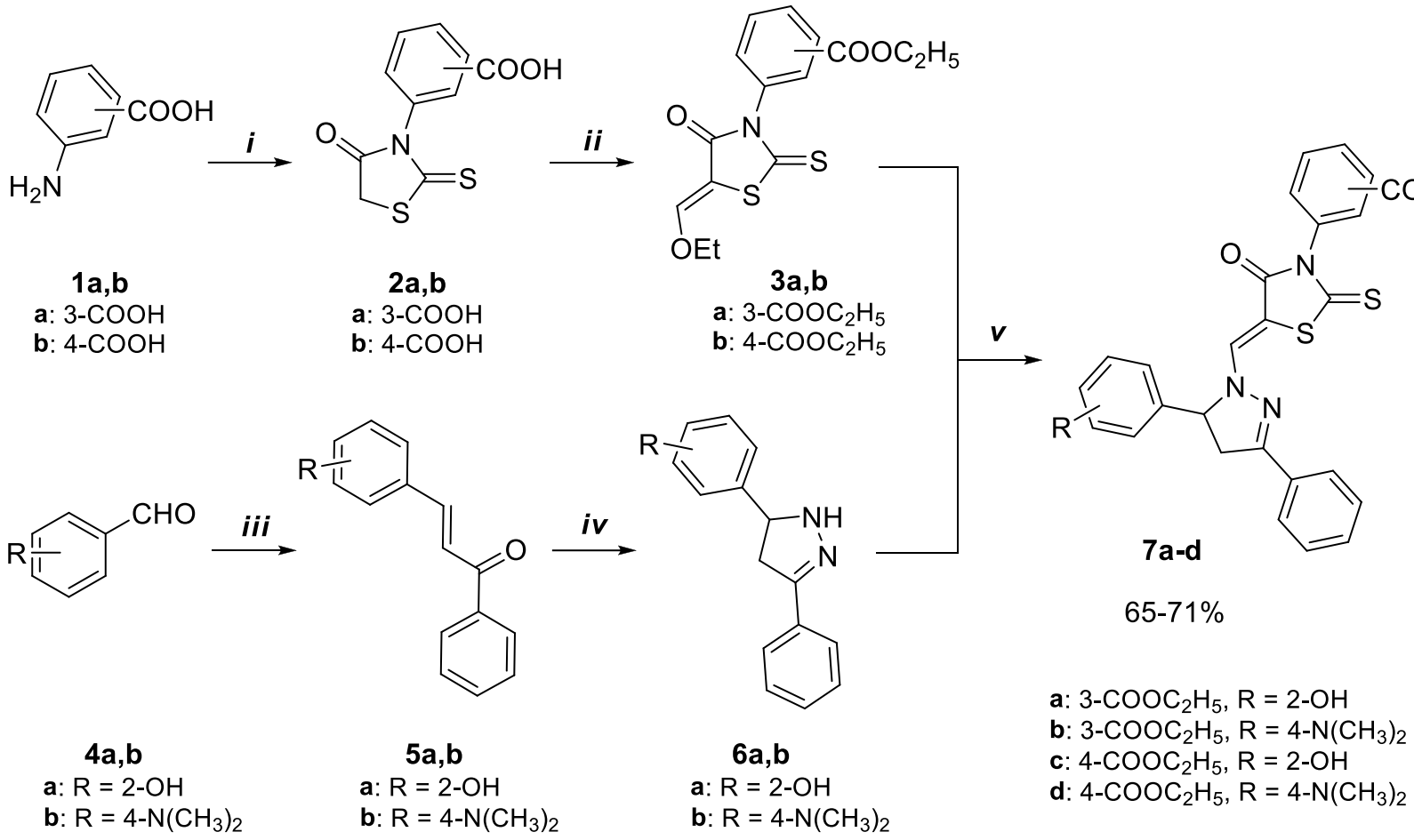

Scheme 1. Synthesis of target pyrazoline-thiazolidin-4-one hybrids 7a-d. Reagents and conditions: $i) \mathbf{1 a}, \mathbf{b}(10 \mathrm{mmole}), \mathrm{CS}\left(\mathrm{SCH} \mathrm{COOH}_{2}\right.$ (10 mmole), $\mathrm{C}_{2} \mathrm{H}_{5} \mathrm{OH}: \mathrm{H}_{2} \mathrm{O}$, reflux, 5h; ii) 2a, b (10 mmole), $\mathrm{HC}\left(\mathrm{OC}_{2} \mathrm{H}_{5}\right)_{3}(10 \mathrm{mmole}), \mathrm{Ac}_{2} \mathrm{O}$, reflux, 3h; iii) 4a, b (10 mmole), acetophenone (10 mmole), $\left.\mathrm{NaOH}(10 \mathrm{mmole}) ; i v) \mathbf{5 a}, \mathbf{b}(10 \mathrm{mmole}), \mathrm{NH}_{2}-\mathrm{NH}_{2}(10 \mathrm{mmole}), \mathrm{KOH}(10 \mathrm{mmole}), \mathrm{C}_{2} \mathrm{H}_{5} \mathrm{OH} ; v\right) \mathbf{3 a}, \mathbf{b}(10$ mmole), 6a, b (10 mmole), $\mathrm{C}_{2} \mathrm{H}_{5} \mathrm{OH}$, reflux, $2 \mathrm{~h}$.

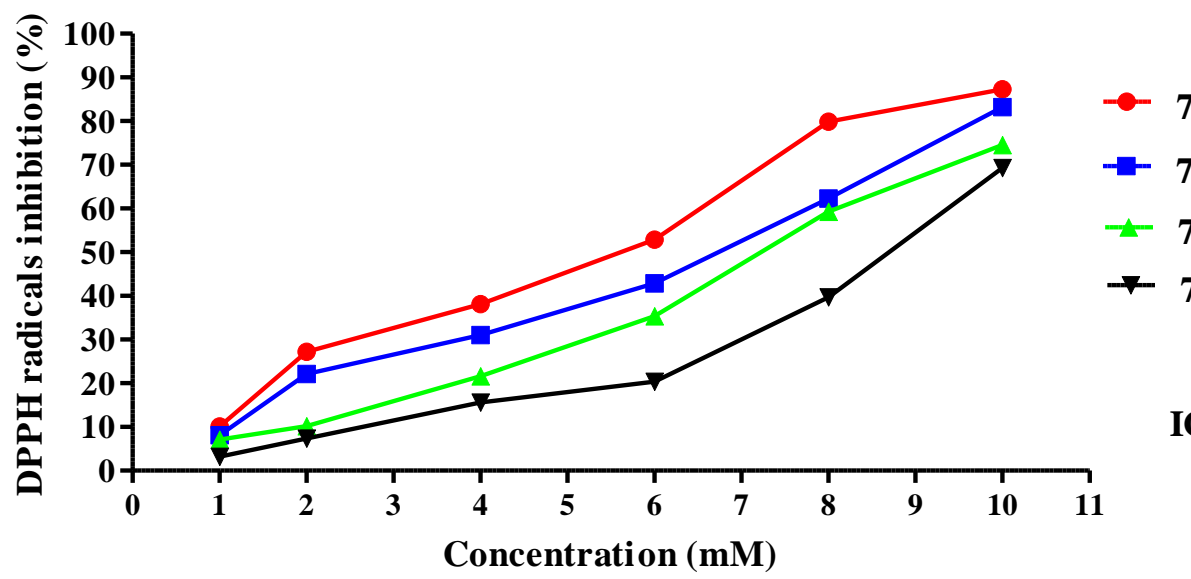

$7 \mathrm{a}, \mathrm{IC}_{50}=4.67 \mathrm{mM}, \mathrm{R}^{2}=0.93$

$7 \mathrm{~b}, \mathrm{IC}_{50}=5.90 \mathrm{mM}, \mathrm{R}^{2}=0.92$

$7 \mathrm{c}, \mathrm{IC}_{50}=6.05 \mathrm{mM}, \mathrm{R}^{2}=0.97$

$7 \mathrm{~d}, \mathrm{IC}_{50}=7.12 \mathrm{mM}, \mathrm{R}^{2}=0.92$

Ascorbic acid

$\mathrm{IC}_{50}=0.045 \mathrm{mM}, \mathrm{R}^{2}=0.99$

Figure 2. The dose-depending DPPH radical inhibition and $\mathrm{IC}_{50}$ values for compounds 7a-d.

the plant seeds and incubated in a minimal medium. Seed germination was observed after 3 days, and only compound 7b inhibited of grass growth by $15 \%$. No inhibitory effect on A. stolonifera was observed in the case of compounds 7a, 7c, and 7d.

The redox activity of 7a-d was evaluated by cyclic voltammetry technique using stock solutions of compounds in methanol $(\mathrm{C}=5 \mathrm{mM})$ with the addition of phosphate buffer solution $(\mathrm{pH}=6.40)$. The glassy carbon working electrode, a platinum wire counter, and a saturated calomel electrode were used, and the measurements were performed at $0 \mathrm{~min}$ and after $60 \mathrm{~min}$ in the potential range from $-1500 \mathrm{mV}$ to $1500 \mathrm{mV}$ with scan rates between 10 and $100 \mathrm{mV} / \mathrm{s}$. No redox peaks were observed under mentioned experimental conditions in cyclic voltammetry studies for tested compounds $\mathbf{7 a - d}$. 
Table 1. Antimicrobial properties of compounds 7a-d (MICs values)

\begin{tabular}{cccc}
\hline $\begin{array}{c}\text { Compounds/ } \\
\text { Microorganisms }\end{array}$ & E.coli & L. plantarum & C. albicans \\
\hline $\mathbf{7 a}$ & $2.5 \mathrm{mM}$ & $>2.5 \mathrm{mM}$ & $>2.5 \mathrm{mM}$ \\
$\mathbf{7 b}$ & $>2.5 \mathrm{mM}$ & $>2.5 \mathrm{mM}$ & $2.5 \mathrm{mM}$ \\
$\mathbf{7 c}$ & $1.25 \mathrm{mM}$ & $>2.5 \mathrm{mM}$ & $2.5 \mathrm{mM}$ \\
$\mathbf{7 d}$ & $2.5 \mathrm{mM}$ & $>2.5 \mathrm{mM}$ & $3.25 \mathrm{mM}$ \\
References $^{\mathrm{a}, \mathrm{b}}$ & $36.5 \mu \mathrm{M}^{\mathrm{a}}$ & $39.8 \mu \mathrm{M}^{\mathrm{a}}$ & $38.96 \mathrm{M}^{\mathrm{b}}$ \\
\hline$-\quad \mathrm{a}-$ ampicillin & & &
\end{tabular}

\section{Conclusions}

In the present paper, a synthesis of the series of new pyrazoline-thiazolidin-4-one hybrids has been reported. The structure of the compounds was confirmed using ${ }^{1} \mathrm{H}$, ${ }^{13} \mathrm{C}$ NMR, and LC-MS spectra. All synthesized compounds were evaluated for their antioxidant, antibacterial, antifungal, herbicidal, and redox properties. The synthesized hybrid compounds have promising free radical scavenging activities, and obtained results argue to the next development of antioxidant agents among these types of molecules.

\section{Experimental section}

\section{General}

Commercial reagents were purchased from Merck and used without purification. Melting points were measured in open capillary tubes on a BÜCHI B-545 melting point apparatus and are uncorrected. The elemental analyses $(\mathrm{C}$, $\mathrm{H}, \mathrm{N})$ was performed using the Perkin-Elmer $2400 \mathrm{CHN}$ analyzer and was within $\pm 0.4 \%$ of the theoretical values. The ${ }^{1} \mathrm{H}$ and ${ }^{13} \mathrm{C}$ NMR spectra were recorded on a Bruker500 spectrometer at $500 \mathrm{MHz}$ and $126 \mathrm{MHz}$ using a mixture of DMSO-d6+CCl4 as a solvent and TMS as an internal standard. Chemical shift values are reported in ppm units with use of $\delta$ scale. Mass spectra were obtained using electrospray ionization (ESI) techniques on an Agilent 1100 Series LCMS. The purity of the compounds was checked by thin-layer chromatography performed with Merck Silica Gel 60 F254 aluminum sheets. Spots were detected by their absorption under UV light.

\section{Synthesis}

General procedure for the synthesis derivatives 7 a-d.

In a round bottom flask is placed by 0.01 mole of $\mathbf{3 a}$ or $\mathbf{3 b}$ and $\mathbf{6 a}$ or $\mathbf{6 b}$, add $10 \mathrm{ml}$ of ethanol. The mixture was heated at reflux for 2 hours. After cooling, the precipitate formed is filtered off and recrystallized from DMFethanol.
Ethyl (Z)-3-(5-(ethoxymethylene)-4-oxo-2-thioxothiazolidin-3-yl)benzoate (3a)

Yield 52\%, mp $163-165^{\circ} \mathrm{C} .{ }^{1} \mathrm{H}$ NMR (500 MHz, DMSO-d $d_{6} \delta 7.99(\mathrm{~s}, 1 \mathrm{H}), 7.90(\mathrm{~s}, 1 \mathrm{H}), 7.47-7.55(\mathrm{~m}, 2 \mathrm{H})$, $4.35(\mathrm{q}, J 6.2 \mathrm{~Hz}, 2 \mathrm{H}), 4.15(\mathrm{q}, J 6.3 \mathrm{~Hz}, 2 \mathrm{H}), 1.35(\mathrm{t}$, $J 6.2 \mathrm{~Hz}, 3 \mathrm{H}), 1.15(\mathrm{t}, J 6.3 \mathrm{~Hz}, 3 \mathrm{H}) . \mathrm{LC} / \mathrm{MS} \mathrm{m} / \mathrm{z} 338$ $(\mathrm{M}+\mathrm{H})^{+}$. Anal. Calcd. for $\mathrm{C}_{15} \mathrm{H}_{15} \mathrm{NO}_{4} \mathrm{~S}_{2}$ : C, 53.40; H, 4.48; N, 4.15. Found: C, 53.50; H, 4.60; N, 4.20.

Ethyl (Z)-4-(5-(ethoxymethylene)-4-oxo-2-thioxothiazolidin-3-yl)benzoate (3b)

Yield $63 \%, \mathrm{mp} 187-189{ }^{\circ} \mathrm{C} .{ }^{1} \mathrm{H}$ NMR $(500 \mathrm{MHz}$, DMSO-d $d_{6} \delta 7.90(\mathrm{~s}, 1 \mathrm{H}), 7.84(\mathrm{~d}, J 8.6 \mathrm{~Hz}, 2 \mathrm{H}), 7.69(\mathrm{~d}$, $J 8.6 \mathrm{~Hz}, 2 \mathrm{H}), 4.35$ (q, $J 6.2 \mathrm{~Hz}, 2 \mathrm{H}), 4.15$ (q, J $6.3 \mathrm{~Hz}$, $2 \mathrm{H}), 1.35(\mathrm{t}, J 6.2 \mathrm{~Hz}, 3 \mathrm{H}), 1.15(\mathrm{t}, J 6.3 \mathrm{~Hz}, 3 \mathrm{H})$. LC/MS $\mathrm{m} / \mathrm{z} 338(\mathrm{M}+\mathrm{H})^{+}$. Anal. Calcd. for $\mathrm{C}_{15} \mathrm{H}_{15} \mathrm{NO}_{4} \mathrm{~S}_{2}$ : C, 53.40; H, 4.48; N, 4.15. Found: C, 53.60; H, 4.50; N, 4.30.

Ethyl (Z)-3-(5-((5-(2-hydroxyphenyl)-3-phenyl-4,5dihydro-1H-pyrazol-1-yl)methylene)-4-oxo-2-thioxothiazolidin-3-yl)benzoate (7a)

Yield $65 \%, \mathrm{mp} 212-214{ }^{\circ} \mathrm{C} .{ }^{1} \mathrm{H}$ NMR $(500 \mathrm{MHz}$, DMSO- $\left.d_{6}\right) \delta 9.53(\mathrm{~s}, 1 \mathrm{H}), 8.10-8.00(\mathrm{~m}, 2 \mathrm{H}), 7.99-7.91$ (m, 2H), 7.69-7.57 (m, 3H), 7.49-7.39 (m, 3H), 7.28-7.22 (m, 2H), 6.81-6.75 (m, 2H), $5.56(\mathrm{dd}, J 11.3,7.0 \mathrm{~Hz}, 1 \mathrm{H})$, 4.31 (q, J $6.3 \mathrm{~Hz}, 2 \mathrm{H}), 4.00$ (dd, J 18.4, $11.3 \mathrm{~Hz}, 1 \mathrm{H}), 3.51$ (dd,

$J$ 18.4, 7.0 Hz, 1H), 1.00 (t, J $6.3 \mathrm{~Hz}, 3 \mathrm{H}) .{ }^{13} \mathrm{C}$ NMR $(126$ MHz, DMSO- $\left.d_{6}\right) \delta 186.5,179.3,167.2,164.1,161.4$, $159.4,157.2,154.0,151.1,149.4,142.2,139.0,137.4$, 129.7, 128.3, 127.0, 126.2, 121.2, 118.4, 113.9, 92.4, 88.7, 62.5, 13.4. LC/MS m/z $530(\mathrm{M}+\mathrm{H})^{+}$. Anal. Calcd. for $\mathrm{C}_{28} \mathrm{H}_{23} \mathrm{~N}_{3} \mathrm{O}_{4} \mathrm{~S}_{2}$ : C, 63.50; $\mathrm{H}, 4.38 ; \mathrm{N}$, 7.93. Found: $\mathrm{C}$, 63.70; H, 4.50; N, 8.00.

Ethyl (Z)-3-(5-((5-(4-(dimethylamino)phenyl)-3-phenyl4,5-dihydro-1H-pyrazol-1-yl)methylene)-4-oxo-2-thioxothiazolidin-3-yl)benzoate ( $7 \boldsymbol{b})$

Yield $67 \%, \mathrm{mp} 228-231{ }^{\circ} \mathrm{C} .{ }^{1} \mathrm{H}$ NMR $(500 \mathrm{MHz}$, DMSO- $\left.d_{6}\right) \delta 8.00(\mathrm{dt}, J$ 7.8, $1.4 \mathrm{~Hz}, 1 \mathrm{H}), 7.94-7.89(\mathrm{~m}$, 
2H), $7.78(\mathrm{t}, J 1.9 \mathrm{~Hz}, 1 \mathrm{H}), 7.70-7.59(\mathrm{~m}, 2 \mathrm{H}), 7.60(\mathrm{~s}$, $1 \mathrm{H}), 7.62-7.56(\mathrm{~m}, 1 \mathrm{H}), 7.58-7.51(\mathrm{~m}, 1 \mathrm{H}), 7.41(\mathrm{~s}, 1 \mathrm{H})$, $7.26-7.21(\mathrm{~m}, 2 \mathrm{H}), 6.79-6.73(\mathrm{~m}, 2 \mathrm{H}), 5.57(\mathrm{dd}, J 11.3,7.1$ $\mathrm{Hz}, 1 \mathrm{H}), 4.31$ (q, J $6.3 \mathrm{~Hz}, 2 \mathrm{H}), 4.00(\mathrm{dd}, J 18.4,11.3 \mathrm{~Hz}$, $1 \mathrm{H}), 3.51(\mathrm{dd}, J 18.5,7.1 \mathrm{~Hz}, 1 \mathrm{H}), 2.90(\mathrm{~s}, 6 \mathrm{H}), 1.31(\mathrm{t}, J$ $6.3 \mathrm{~Hz}, 3 \mathrm{H}) .{ }^{13} \mathrm{C}$ NMR (126 MHz, DMSO- $\left.d_{6}\right) \delta 184.4$, $179.5,166.5,163.6,160.9,159.5,156.8,154.1,150.5$, $148.5,141.7,138.5,137.1,129.2,128.1,127.3,125.8$, 120.6, 116.3, 112.6, 91.5, 88.7, 64.4, 35.2, 13.1. LC/MS $\mathrm{m} / \mathrm{z} 557(\mathrm{M}+\mathrm{H})^{+}$. Anal. Calcd. for $\mathrm{C}_{30} \mathrm{H}_{28} \mathrm{~N}_{4} \mathrm{O}_{3} \mathrm{~S}_{2}$ : C, 64.73; H, 5.07; N, 10.06. Found: C, 64.90; H, 5.20; N, 10.20 .

Ethyl (Z)-4-(5-((5-(2-hydroxyphenyl)-3-phenyl-4,5dihydro-1H-pyrazol-1-yl)methylene)-4-oxo-2thioxothiazolidin-3-yl)benzoate (7c)

Yield $68 \%, \mathrm{mp} 230-232{ }^{\circ} \mathrm{C} .{ }^{1} \mathrm{H}$ NMR $(500 \mathrm{MHz}$, DMSO-d $d_{6} \delta 9.50(\mathrm{~s}, 1 \mathrm{H}), 8.11-8.02(\mathrm{~m}, 2 \mathrm{H}), 7.96-7.89$ $(\mathrm{m}, 2 \mathrm{H}), 7.64-7.53(\mathrm{~m}, 3 \mathrm{H}), 7.48-7.38(\mathrm{~m}, 3 \mathrm{H}), 7.25-7.20$ $(\mathrm{m}, 2 \mathrm{H}), 6.81-6.74(\mathrm{~m}, 2 \mathrm{H}), 5.56(\mathrm{dd}, J 11.3,7.0 \mathrm{~Hz}, 1 \mathrm{H})$, 4.31 (q, $J 6.3 \mathrm{~Hz}, 2 \mathrm{H}), 4.00(\mathrm{dd}, J 18.4,11.3 \mathrm{~Hz}, 1 \mathrm{H}), 3.51$ $(\mathrm{dd}, J 18.4,7.0 \mathrm{~Hz}, 1 \mathrm{H}), 1.05(\mathrm{t}, J 6.3 \mathrm{~Hz}, 3 \mathrm{H}) .{ }^{13} \mathrm{C} \mathrm{NMR}$ $\left(126 \mathrm{MHz}, \mathrm{DMSO}-d_{6}\right) \delta 184.0,179.1,166.8,162.9,160.7$, $159.2,156.8,153.3,150.4,141.5,138.3,137.2,129.7$, 129.4, 128.3, 127.5, 126.9, 113.1, 91.1, 86.5, 64.0, 13.2. $\mathrm{LC} / \mathrm{MS} \mathrm{m} / \mathrm{z} 530(\mathrm{M}+\mathrm{H})^{+}$. Anal. Calcd. for $\mathrm{C}_{28} \mathrm{H}_{23} \mathrm{~N}_{3} \mathrm{O}_{4} \mathrm{~S}_{2}$ : C, 63.50; H, 4.38; N, 7.93. Found: C, 63.80; H, 4.60; N, 8.10.

Ethyl (Z)-4-(5-((5-(4-(dimethylamino)phenyl)-3-phenyl4,5-dihydro-1H-pyrazol-1-yl)methylene)-4-oxo-2thioxothiazolidin-3-yl)benzoate (7d)

Yield $71 \%, \mathrm{mp} 244-246{ }^{\circ} \mathrm{C} .{ }^{1} \mathrm{H}$ NMR (500 MHz, DMSO-d $\left.{ }_{6}\right) \delta 8.09-8.00(\mathrm{~m}, 2 \mathrm{H}), 7.94-7.88(\mathrm{~m}, 2 \mathrm{H}), 7.65-$ $7.55(\mathrm{~m}, 3 \mathrm{H}), 7.48-7.38(\mathrm{~m}, 3 \mathrm{H}), 7.26-7.20(\mathrm{~m}, 2 \mathrm{H}), 6.79-$ $6.72(\mathrm{~m}, 2 \mathrm{H}), 5.56(\mathrm{dd}, J 11.3,7.0 \mathrm{~Hz}, 1 \mathrm{H}), 4.31(\mathrm{q}$, $J 6.3 \mathrm{~Hz}, 2 \mathrm{H}), 4.00$ (dd, $J$ 18.4, $11.3 \mathrm{~Hz}, 1 \mathrm{H}), 3.51$ (dd, $J$ 18.4, 7.0 Hz, 1H), $2.90(\mathrm{~s}, 6 \mathrm{H}), 1.05(\mathrm{t}, J 6.3 \mathrm{~Hz}, 3 \mathrm{H})$. ${ }^{13} \mathrm{C}$ NMR (126 MHz, DMSO- $\left.d_{6}\right) \delta 183.7,178.6,165.7$, $162.7,160.1,158.8,156.2,153.7,150.0,141.3,138.1$, 137.0, 129.9, 129.2, 128.1, 127.3, 126.4, 112.6, 90.8, 86.3, 63.7, 39.0, 13.0. LC/MS m/z $557(\mathrm{M}+\mathrm{H})^{+}$. Anal. Calcd. for $\mathrm{C}_{30} \mathrm{H}_{28} \mathrm{~N}_{4} \mathrm{O}_{3} \mathrm{~S}_{2}$ : C, 64.73; H, 5.07; N, 10.06. Found: C, 65.00; H, 5.10; N, 10.30 .

\section{Antioxidant activity (DPPH assay)}

DPPH inhibition was determined by using the protocol [20]. The DPPH radical is stable due to the delocalization of a spare electron over the molecule, thus preventing dimer formation. This radical is used in the DPPH radical scavenging capacity assay to quantify the ability of antioxidants to quench the DPPH radical. The dark purple color of DPPH will be lost when it is reduced to its nonradical form stable organic nitrogen centered free radical with a dark purple color which when reduced to its nonradical form by antioxidants becomes colorless. DPPH radicals are widely used in the model system to investigate the scavenging activities of several natural compounds. When the DPPH radical is scavenged, the color of the reaction mixture changes from purple to yellow with decreasing of absorbance at wavelength $517 \mathrm{~nm}$. The stock solutions of compounds were prepared in mixture methanol + Tris- $\mathrm{HCl}$ buffer $\mathrm{pH}=7.40$. Then $1 \mathrm{~mL}$ of DPPH $(8 \mathrm{mg} / 100 \mathrm{~mL}$ of methanol) solution was added to the sample and the blank. This setup was left at room temperature for $30 \mathrm{~min}$ (vortexed in between). Absorbance was taken at $517 \mathrm{~nm}$ against the ethanol by using UV1800 spectrophotometer (Shimadzu, Japan). Each sample was analyzed in triplicate. The percentage of inhibition was calculated against blank:

$$
\mathrm{I} \%=\left(\mathrm{A}_{\text {blank }}-\left(\mathrm{A}_{\text {sample }}+\mathrm{dpph}-\mathrm{A}_{\text {sample }}\right)\right) / \mathrm{A}_{\text {blank }} \times 100 \%,
$$

where $A_{\text {blank }}$ - is the absorbance of the control reaction (containing all reagents except the tested compounds); $\mathrm{A}_{\text {sample+dpph }}$ - is the absorbance of the tested compounds after 60 min incubation with DPPH solution;

$\mathrm{A}_{\text {sample }}$ - is the absorbance of the tested compounds without DPPH solution.

\section{Antimicrobial activity}

The minimal inhibitory concentrations (MICs) were determined by the standard microdilution method in cation-adjusted Mueller-Hinton II Broth (MHB, BectonDickinson, Germany) according to the recommendations of the Clinical and Laboratory Standard Institute. The tested compounds were evaluated for their antimicrobial activity against Gram-positive bacteria (L. plantarum), Gram-negative bacteria (E. coli), and yeasts (C. albicans). Ampicillin was used as a reference antibacterial agent and fluconazole as antifungal one. A representative colony was lifted off with a wire loop and placed in $5 \mathrm{~mL}$ of nutrient broth medium, which was then incubated with shaking at $37^{\circ} \mathrm{C}$ for $5 \mathrm{~h}$. Then, $1 \times 10^{6}$ cells $/ \mathrm{mL}$ were suspended in a nutrient broth medium to generate the working suspension. Different concentrations of peptides were prepared in a 96-well plate using nutrient broth medium, and each well contained $100 \mu \mathrm{L}$ compound solutions. A $100-\mu \mathrm{L}$ cell working suspension was then added to each well. The plate was incubated at $37^{\circ} \mathrm{C}$ for $24 \mathrm{~h}$, and the optical density (OD) of each well was then measured at $600 \mathrm{~nm}$ after gently shaking the plate for 10s using a Hybrid MultiMode Microplate reader (BioTek, Synergy H4). Wells containing medium only (blank) and wells containing cells in medium without peptides (positive control) were included on the same plate. The values of MIC were recorded after $20 \mathrm{~h}$ and $24 \mathrm{~h}$ of incubation with the compounds for bacteria and yeasts, respectively. Experiments were performed in triplicate and on three different occasions (i.e., a total of nine repeats for each individual measurement).

\section{Herbicidal activity - Herbicidal Pre-emergence Test}

Seeds of A. stolonifera (JuliwaHESA, Heidelberg, Germany) were placed into the wells of a 96-well microtiter plate (Sarstedt, Nümbrecht, Germany). A solution containing $2.2 \mathrm{~g} / \mathrm{l}$ Murashige \& Skoog plant salts (Serva, Heidelberg, Germany) and $1.6 \mathrm{~g} / \mathrm{l}$ Gamborg's B5 
plant medium (Serva, Heidelberg, Germany) was added to the wells. The stock solutions in concentration $1 \mathrm{mg} / \mathrm{ml}$ in methanol were prepared for compounds $7 \mathbf{a}-\mathbf{d}$ and were added to the wells. Identical volumes of methanol without compounds were used as a toxicity test of the organic solvent. The solution containing the plant medium was used as a negative control. The plate was closed and incubated at room temperature under constant light (Osram Fluora lamp) in a humidity chamber. After 3 days of incubation, the plate lid was removed and a container with tap water was placed inside the chamber for increasing the air humidity. The plate was incubated up to 6 days. Three technical replicates were performed.

\section{Voltammetric parameters and electrochemical cells}

Voltammetric experiments were performed using BAS 100W Potentiostat.A glassy carbon $(\mathrm{GC})\left(\mathrm{A}=0.07 \mathrm{~cm}^{2}\right)$ was used as working electrode. $\mathrm{Pt}$ wire and saturated calomel electrode (SCE) were used as counter and reference electrodes. Before each experiment, the surface of GCE was polished with diamond spray (particle size 1 $\mu \mathrm{m})$ followed by thorough rinsing with distilled water. All the voltammetric experiments were conducted in a high purity nitrogen atmosphere at room temperature $\left(25 \pm 1{ }^{\circ} \mathrm{C}\right.$ ) potential range from $-1500 \mathrm{mV}$ to $1500 \mathrm{mV}$, scan rates between 10 and $100 \mathrm{mV} / \mathrm{s}$; stock solutions in methanol

$\mathrm{C}=5 \mathrm{mM}$, PBS $\mathrm{pH}=6.40$; measurements at 0 and after $60 \mathrm{~min}$. For reproducible experimental results, the polished working electrode was used to place in the desired electrolyte solution followed by recording of various voltammograms until the achievement of steady state baseline.

\section{Notes}

Acknowledgments and finances. This work was partially supported by COST Action NutRedOx-CA16112 "Personalized Nutrition in ageing society: redox control of major age-related diseases". The author is grateful to A. Luzhetskyy, A. Palusczak and M. Stierhof (Department of Pharmaceutical Biotechnology, Saarland University, Germany), for support with LC-MS, NMR spectra, and herbicidal activity study.

\section{The author declare no conflict of interest.}

\section{References}

1. Sies, H.; Jones, D. P. Reactive oxygen species (ROS) as pleiotropic physiological signalling agents. Nat. Rev. Mol. Cell. Biol. 2020, 21 , 363-383.

2. Zarkovic, N. Roles and Functions of ROS and RNS in Cellular Physiology and Pathology. Cells 2020, 9, 767.

3. Sova, M.; Saso, L. Design and development of Nrf2 modulators for cancer chemoprevention and therapy: a review. Drug. Des. Devel. Ther. 2018, 12, 3181-3197.

4. Freitas, R. H. C. N.; Fraga, C. A. M. NF-kB-IKK $\beta$ Pathway as a Target for Drug Development: Realities, Challenges and Perspectives. Curr. Drug. Targets. 2018, 19, 1933-1942.
5. Ottanà, R.; Maccari, R.; Giglio, M.; Del Corso; A., Cappiello; M., Mura, U.; Cosconati, S.; Marinelli, L.; Novellino, E.; Sartini, S. et al. Identification of 5-arylidene-4-thiazolidinone derivatives endowed with dual activity as aldose reductase inhibitors and antioxidant agents for the treatment of diabetic complications. Eur. J. Med. Chem. 2011, 46, 2797-806.

6. Kumar, V.; Sharma, A.; Sharma, P. C. Synthesis of some novel 2,5disubstituted thiazolidinones from a long chain fatty acid as possible anti-inflammatory, analgesic and hydrogen peroxide scavenging agents. J. Enzyme Inhib. Med. Chem. 2011, 26, 198203.

7. Raut, D. G.; Lawand, A. S.; Kadu, V. D.; Hublikar, M. G.; Patil, S. B.; Bhosale, D. G.; Bhosale, R. B. Synthesis of Asymmetric Thiazolyl Pyrazolines as a Potential Antioxidant and AntiInflammatory Agents. Polycycl. Arom. Comp. 2020, 1-10.

8. Upadhyay, N.; Tilekar, K.; Loiodice, F.; Anisimova, N. Y.; Spirina, T. S.; Sokolova, D. V.; Smirnova, G. B.; Choe, J. Y.; Meyer-Almes, F. J.; Pokrovsky, V. S.; Lavecchia, A.; Ramaa, C. S. Pharmacophore hybridization approach to discover novel pyrazoline-based hydantoin analogs with anti-tumor efficacy. Bioorg. Chem. 2020, 107, 104527.

9. Borcherding, D. C.; Siefert, M. E., Lin, S., Brewington, J., Sadek, H., Clancy, J. P., Plafker, S. M., Ziady, A. G. Clinically approved CFTR modulators rescue Nrf2 dysfunction in cystic fibrosis airway epithelia. J. Clin. Invest. 2019, 129, 3448-3463.

10. Robledinos-Antón, N.; Fernández-Ginés, R.; Manda, G.; Cuadrado, A. Activators and Inhibitors of NRF2: A Review of Their Potential for Clinical Development. Oxid. Med. Cell. Longev. 2019, 2019, 9372182.

11. Lu, M.; Zhang, X., Zhao, J.; You, Q.; Jiang, Z. A hydrogen peroxide responsive prodrug of Keap1-Nrf2 inhibitor for improving oral absorption and selective activation in inflammatory conditions. Redox Biol. 2020, 34, 101565.

12. Derkach, G. O.; Golota, S. M.; Trufin, Y. O.; Roman, O. M.; Sementsiv, G. M.; Demchuk, I. L.; Soronovych, I. I.; Kutsyk, R. V.; Grellier, P.; Lesyk, R. B. Synthesis and biological activity of 5aminomethylene-2-thioxotiazolidin-4-ones derivatives. Pharm. Rev. 2017, 2, 5-11 (In Ukrainian).

13. Derkach, G. O.; Golota, S. M.; Zasidko, V. V.; Soronovych, I. I.; Kutsyk, R. V.; Lesyk, R. B. The synthesis and the study of antimicrobial properties of 5-r,r'-aminometylene derivatives of thiazolidine-2, 4-dione and 4-thioxothiazolidine-2-one. J. Org. Pharm. Chem. 2016, 14, 32-37.

14. Holota, S. M.; Derkach, G. O.; Zasidko, V. V.; Trokhymchuk, V. V.; Furdychko, L. O.; Demchuk, I. L.; Semenciv, G. M.; Soronovych, I. I.; Kutsyk, R. V.; Lesyk, R. B. Features of antimicrobial activity of some 5-aminomethylene-2-thioxo-4thiazolidinones. Biopolym. Cell. 2019, 35, 371-380.

15. Holota, S.; Kryshchyshyn, A.; Derkach, H.; Trufin, Y.; Demchuk, I.; Gzella, A.; Grellier, P.; Lesyk, R. Synthesis of 5-enamine-4thiazolidinone derivatives with trypanocidal and anticancer activity. Bioorg Chem. 2019, 86, 126-136.

16. Holota, S.M.; Derkach, H. O.; Demchuk, I. L.; Vynnytska, R. B.; Antoniv, O. I.; Furdychko, L. O.; Nektegayev, I.O.; Lesyk, R. B. Synthesis and in vivo evaluation of pyrazoline-thiazolidin-4-one hybrid Les-5581 as a potential non-steroidal anti-inflammatory agent. Biopolym.Cell., 2019, 35, 437-447.

17. Ajantha, J.; Varathan, E.; Bharti, V.; Subramanian, V.; Easwaramoorthi, S.; Chand, S. Photophysical and charge transport properties of pyrazolines. RSC Adv. 2016, 6, 786-795.

18. Radi, M.; Botta, L.; Casaluce, G.; Bernardini, M.; Botta, M. Practical One-Pot Two-Step Protocol for the Microwave-Assisted Synthesis of Highly Functionalized Rhodanine Derivatives. $J$. Comb. Chem. 2010, 12, 200-205.

19. Chebanov, V. A.; Desenko, S. M.; Gurley, T. W. Azaheterocycles based on a, $\beta$-unsaturated carbonyls, Springer-Verlag Berlin Heidelberg, 2008.

20. Brand-Williams, W.; Cuvelier, M.; Berset, C. Use of a free radical method to evaluate antioxidant activity. LWT - Food Science and Technology, 1995, 28, 25-30.

21. Humphries, R.M.; Ambler, J.; Mitchell, S.L.; Castanheira, M.; Dingle, T.; Hindler, J.A.; Koeth, L.; Sei, K. CLSI Methods Development and Standardization Working Group Best Practices for Evaluation of Antimicrobial Susceptibility Tests. J. Clin. Microbiol. 2018, 56, e01934-1917.

22. Nenoff, P.; Oswald, U.; Haustein, U.F. In vitro susceptibility of yeasts for fluconazole and itraconazole. Evaluation of a microdilution test. Mycoses, 1999, 42, 629-639. 


\section{Синтез нових піразолін-тіазолідин-4-онових гібридних молекул та оцінка їх біологічної активності}

\section{С. М. Голота ${ }^{1,2 *}$}

${ }^{1}$ Львівський національний медичний університет імені Данила Галицького, вул. Пекарська, 69, Львів, 79010, Украӥна

${ }^{2}$ Волинський національний університет імені Лесі Украӥнки, просп. Волі, 13, Луцьк, 43025, Украӥна

Резюме: Протягом останніх десятиріч гібридні молекули на основі піразолінових та тіазолідин-4-онових каркасів є об'єктом інтенсивних досліджень в медичній хімії як джерело потенційних біологічно активних сполук із широким фармакологічним профілем. В даній роботі запропонований та представлений ефективний підхід до синтезу піразолін-тіазолідин-4-онових гібридних молекул з єнаміновим лінкером у молекулах. Структура синтезованих сполук підтверджена 3 використанням методів ${ }^{1} \mathrm{H}-,{ }^{13} \mathrm{C}-Я М Р$ спектроскопії та РХ-МС-спектрометрії. Для всіх сполук досліджена антиоксидантна (DPPH метод), протимікробна (по відношенню до грам-позитивних Lactobacillus plantarum, грамнегативних Escherichia coli та грибів Candida albicans, визначення МІК), редокс (метод циклічної вольтметрії) та гербіцидна активності (по відношенню до Agrostis stolonifera). Всі тестовані сполуки продемонстрували здатність інгібувати радикали в умовах DPРН-тесту з $\mathrm{IC}_{50}$ в межах 4.67-7.12 mM. Отримані результати скринінгу антирадикальної активності є аргументом для поглиблених досліджень із застосуванням додаткових/альтернативних експериментальних моделей, а також оптимізації молекулярної структури. Всі тестовані сполуки проявили низьку протимікробну та гербіцидну активності, а також не володіють редокс-властивостями.

Ключові слова: піразолін-тіазолідин-4-онові гібриди; метод DPPH; протимікробна/гербіцидна активність; циклічна вольтметрія. 